\title{
Exemplary Youth Leadership Series: Activities to Engage Youth With Practices of Exemplary Leaders ${ }^{1}$
}

\author{
Megan Stein²
}

This publication series is designed to outline strategies and experiences to expose youth to and engage them with leadership concepts. In this series, activities have been developed to introduce youth to Kouzes and Posner's five practices of exemplary leaders (2018). The five practices are: model the way, inspire a shared vision, challenge the process, enable others to act, and encourage the heart (Kouzes \& Posner, 2018). Each article in the series directly relates to one of the practices and the topics of values, vision, teamwork, trust, and gratitude. This first publication in the series introduces each practice and Kolb's Experiential Learning Model.

Each article will have a brief overview of the practice and quick, low-cost activities that can be implemented in meetings, camps, or training. This material requires no previous knowledge of leadership theory or concepts. This series is designed for implementation by Extension professionals, $4-\mathrm{H}$ volunteers, or youth counselors. While this content and activities are best suited for students ages 10-18, modifications are included for each of the activities to allow for different group sizes, ages, and abilities of the youth involved.

\section{Introduction to the Five Practices of Exemplary Leaders}

The five practices of exemplary leaders were designed to mobilize leaders to begin a process of transformation in themselves and their communities (Kouzes \& Posner, 2018). While the five practices were originally designed with adult leaders in mind, a student leadership practices inventory has since been developed. These accessible, everyday practices have been intentionally reconfigured with the hopes of moving youth toward a better future. The foundation of the approach is rooted in the belief that anyone can be a leader. There are no traits, requirements, or positions that give individuals the right to be a leader. Rather, leadership is a behavior.

Through observation of individuals' self-identified best experiences as leaders, Kouzes and Posner (2018) identified that leaders follow a similar path when enacting change, regardless of the situation. It was during this research in the late 1980s that the five practices of exemplary leaders were identified and shared. While the context of leadership shifts over time, the behaviors and actions associated with leadership remain unchanged, and these five practices are still widely used and taught at universities across the globe (Kouzes \& Posner, 2018).

Modeling the way focuses on a leader's ability to identify personal and group values and then align their actions with their intentions. To inspire a shared vision, leaders envision

1. This document is AEC681, one of a series of the Department of Agricultural Education and Communication, UF/IFAS Extension. Original publication date October 2019. Visit the EDIS website at https://edis.ifas.ufl.edu for the currently supported version of this publication.

2. Megan Stein, lecturer, Department of Agricultural Education and Communication; UF/IFAS Extension, Gainesville, FL 32611.

The Institute of Food and Agricultural Sciences (IFAS) is an Equal Opportunity Institution authorized to provide research, educational information and other services

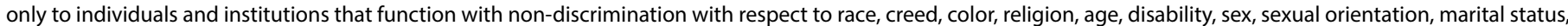

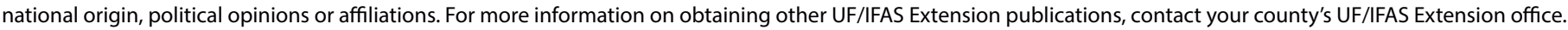
U.S. Department of Agriculture, UF/IFAS Extension Service, University of Florida, IFAS, Florida A \& M University Cooperative Extension Program, and Boards of County Commissioners Cooperating. Nick T. Place, dean for UF/IFAS Extension. 
a positive change they wish to enact and recruit people to assist in achieving the goal. Challenging the process involves leaders innovating to find solutions and taking risks with their implementation. Enabling others to act is centered on leaders developing trust and a strong team with their followers. Finally, encouraging the heart focuses on gratitude and celebrating the victories of the team.

When students can distinguish and understand all five practices, they demonstrate solid leadership skills and behaviors.

\section{Experiential Learning}

When discussing the concepts surrounding leadership activities, one must first understand how each activity should be practiced. The fundamentals of experiential learning allow students to gain applicable knowledge from their experiences, illustrated in Figure 1 (Kolb, 1984).

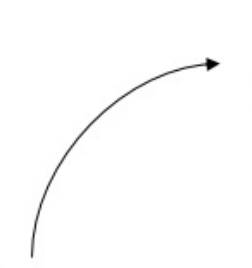

Active

Experimentation

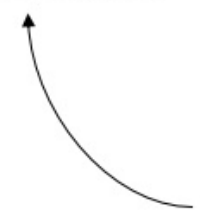

\section{Conceptualization}

Figure 1. Kolb's Model of Experiential Learning Credits: Kolb (1984)

First, students must interact with a concrete experience. This creates a common experience among the students that can be analyzed and referred to throughout the session. In this step, provide only the information necessary to complete the activity accurately and safely. In this series, this step is accomplished by activities students will participate in during a session.

Students then leave the concrete experience phase and enter the second phase, reflective observation. This phase allows students to grasp what they experienced and what they observed through the activity. The presenter should guide the students through this phase by asking questions including, "What just happened?" and "What did you notice?"
Following this, in the abstract conceptualization phase, students make sense of what has happened. Using the activity, their observations, and the group discussion, students develop ideas and theories that help them form conclusions from the experience.

Finally, students enter the active experimentation stage and develop applications of their new knowledge to their personal lives. This can be something continued during the activity or put into practice at a later time.

This series was designed utilizing Kolb's model of experiential learning. When all pieces of the activity are completed, the presenter will have moved students through each stage of this model organically.

\section{Introduction to Facilitating Youth Leadership Activities}

When facilitating youth leadership activities, be sure to pay attention to the following tips (Schuman, 2005):

1. Gain the students' attention-Strategies to gain students' attention include asking questions, telling personal stories, sharing an interesting scenario, and presenting the activity as a challenge.

\section{Ensure all voices are heard-When leading a group} discussion, it is easy to slip and accidentally give students the answer you are looking for. Be sure to ask questions carefully, and give time to allow all students to discover the answers.

3. Have enough time-Make sure that you have enough time to complete each step of the activity and the discussion.

4. Be flexible-Often students will take something from an experience that was not originally intended. If students make a connection you were not originally seeking, be open to the new path but still be firm on the intention of the activity.

5. Have fun!-YYouth are better engaged when the presenter has energy and enthusiasm towards the subject. Smile, relax, and show the students you are just as excited as they are to be experiencing something new. 


\section{Summary}

This publication is the first in the Exemplary Youth Leadership series. This series is designed to be used by Extension professionals, $4-\mathrm{H}$ volunteers, and youth counselors and is focused on developing the five practices of exemplary leaders among youth. Additional publications will provide additional information, examples, and activities to grow this skillset.

\section{References}

Kolb, D. A. (1984). Experiential learning: Experience as the source of learning and development. Upper Saddle River, NJ: Prentice Hall, Inc.

Kouzes, J.M., \& Posner, B.Z. (2018). The student leadership challenge: Five practices for becoming an exemplary leader. San Francisco, CA: John Wiley \& Sons.

Schuman, S., \& International Association of Facilitators. (2005). The IAF handbook of group facilitation: Best practices from the leading organization in facilitation. San Francisco, CA: Jossey-Bass.

\section{Appendix A: Exemplary Youth Leadership Series Overview}

Exemplary Youth Leadership Series: Activities to Engage

Youth With Practices of Exemplary Leaders

Summary of the five practices of exemplary leaders and experiential learning and an introduction to the facilitation of leadership concepts.

Exemplary Youth Leadership Series: Model the Way

Explanation of modeling the way as a leadership practice, centered on exemplifying one's values and activities to present knowledge.

Exemplary Youth Leadership Series: Inspire a Shared Vision

Information on inspiring a shared vision that allows youth to participate in the visioning process through two activities.
Exemplary Youth Leadership Series: Challenge the Process

Challenging the process allows individuals to identify and accept challenges. Activities introduce youth to the concepts of tackling great challenges.

Exemplary Youth Leadership Series: Enable Others to Act

Information on the "enable others to act" practice, focused on trust. Two activities allow youth to build an environment of trust and delegation.

Exemplary Youth Leadership Series: Encourage the Heart

Explanation of the "encourage the heart" practice, which explains the process of recognizing individual contributions and celebrating the victories of others. 